\title{
A New Synthesis of Gefitinib
}

\author{
Taber S. Maskrey \\ Tyler Kristufek \\ Matthew G. LaPorte \\ Prasanth R. Nyalapatla \\ Peter Wipf*
}

Department of Chemistry, University of Pittsburgh, Pittsburgh, PA

15260, USA

pwipf@pitt.edu

Published as part of the 30 Years SYNLETT - Pearl Anniversary Issue<smiles>COc1cc2nc(Cl)nc(Cl)c2cc1OCCCN1CCOCC1</smiles>

en. ${ }^{2}$ In NSCLC, mutation of the EGFR tyrosine kinase domain destabilizes the kinase conformation and affects downstream signaling pathways. ${ }^{3}$ These disruptions stimulate cancer cell proliferation and inhibit apoptosis. Gefitinib reversibly binds to the ATP site of the EGFR kinase domain to inhibit autophosphorylation and signal transduction. ${ }^{4}$

Several syntheses of gefitinib have been described in the literature. $^{5-9}$ AstraZeneca's original synthesis began with the demethylation of 6,7-dimethyoxyquinazoline-4-one with L-methionine and methanesulfonic acid, followed by acetylation, halogenation, aniline nucleophilic aromatic substitution $\left(\mathrm{S}_{\mathrm{N}} \mathrm{Ar}\right)$, deacetylation, and O-alkylation (Scheme 1). ${ }^{10}$ This six-step synthesis (10\% overall yield) required chromatographic purifications and used hazardous reagents, such as thionyl chloride, which reacts violently with water to produce toxic fumes of sulfur dioxide and also contaminates the air very quickly upon evaporation at $20{ }^{\circ} \mathrm{C} .11$

In 2007, Reddy and co-workers reported a synthesis of gefitinib from isovanillin (Scheme 2). ${ }^{12}$ The nitro group in the isovanillin-derived intermediate was reduced with sodium dithionite, followed by treatment with $\mathrm{N}, \mathrm{N}$-dimethylformamide dimethylacetal (DMF-DMA; 1,1-dimethoxyis the most prevalent fatal cancer for both men and wom-
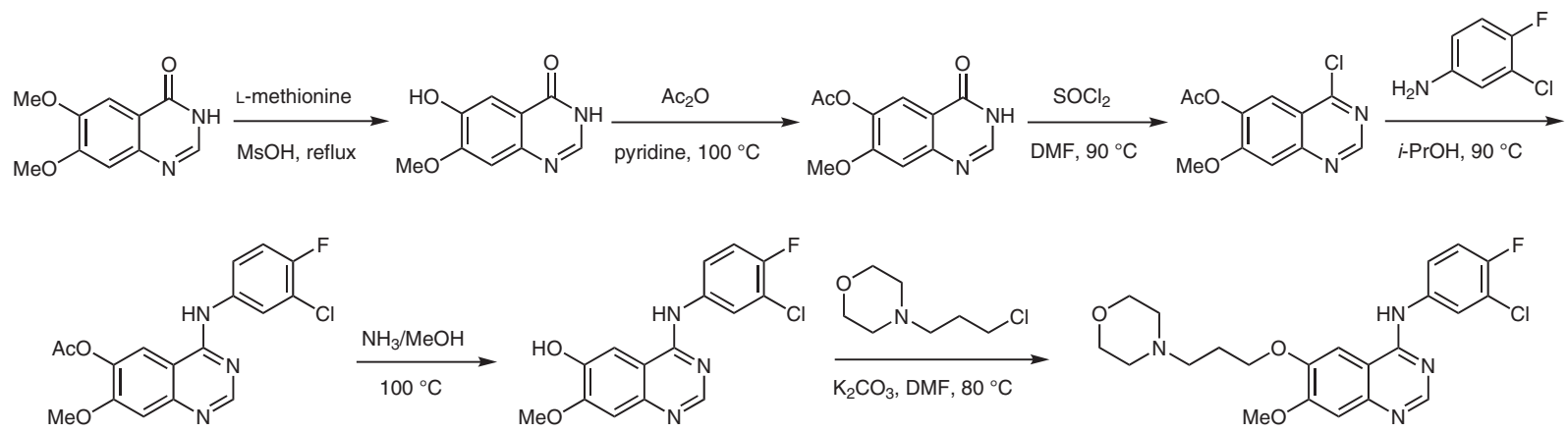<smiles>COc1cc2ncnc(Nc3ccc(F)c(Cl)c3)c2cc1O</smiles><smiles></smiles><smiles>COc1cc2ncnc(Nc3ccc(F)c(Cl)c3)c2cc1OCCCN1CCOCC1</smiles>

Scheme 1 AstraZeneca synthesis of gefitinib ${ }^{10}$ 

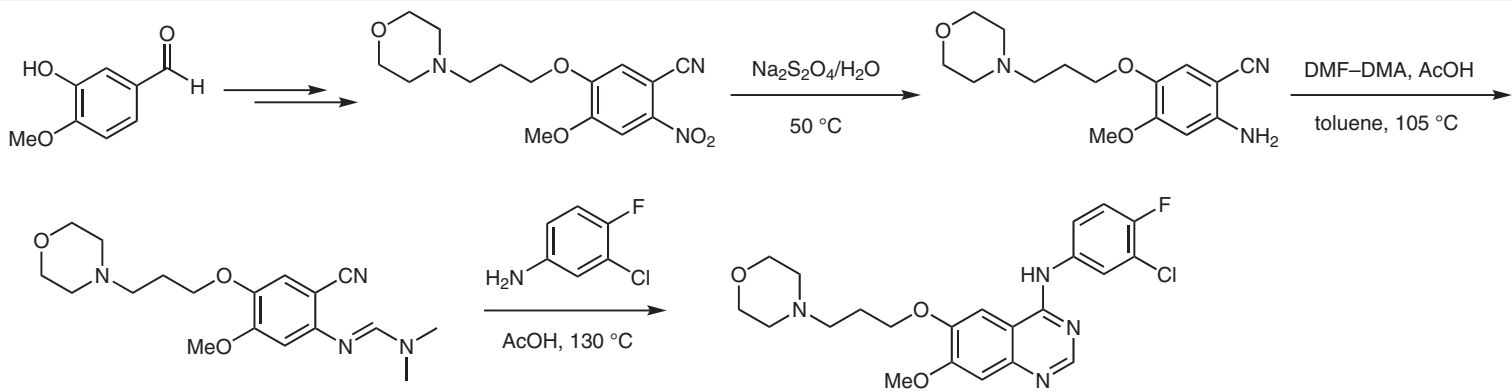

Scheme 2 Reddy and co-workers' synthesis of gefitinib ${ }^{12}$

$\mathrm{N}, \mathrm{N}$-dimethylmethanamine) and amination with 3-chloro4-fluoroaniline to yield the active pharmaceutical ingredient (API). No chromatography was required, but high reaction temperatures were needed, and DMF was used in large quantities in the seven-step synthesis.

More recently, Suh and co-workers reported a variant of the AstraZeneca synthesis that used a transient-protectivegroup strategy (Scheme 3$).{ }^{13}$ An acetylated quinazoline core was subjected to a chlorination with $\mathrm{POCl}_{3}$, substitution with 3-chloro-4-fluoroaniline, and deprotection with $\mathrm{LiOH}$ to set the stage for alkylation with 4-(3-chloropropyl)morpholine, using TMSI to protect the aniline nitrogen transiently. Although high yielding, this synthetic route required hazardous TMSI and a more-elaborate starting material. It also used phosphoryl chloride, which reacts violently with water to produce toxic gases, and is highly corrosive. $^{14}$

We envisioned a new route to gefitinib with fewer than five steps from inexpensive starting materials that would avoid hazardous reagents and chromatographic separations, and would keep reaction temperatures in the $0-60{ }^{\circ} \mathrm{C}$ range. Such a process would be commercially relevant and potentially attractive for pharmaceutical manufacturing. To increase the electrophilic reactivity of the pyrimidine moiety in the $S_{N} A r$ reaction, we chose commercially available 2,4-dichloro-6,7-dimethoxyquinazoline (1) as a starting material. To the best of our knowledge, a synthesis of gefi- tinib or related analogues that utilizes a 2,4-dichloroquinazoline as a starting material or advanced intermediate is unprecedented. We reasoned that the $S_{N} A r$ substitution of the chlorine in the 4-position of the quinazoline would occur preferentially, ${ }^{15}$ and that the 2-position might be readily dechlorinated at a late stage. We did not employ a Buchwald-Hartwig amination of the quinazoline because of concerns regarding the harsh conditions often required and because of the risk of contaminating the API with Pd. Furthermore, several groups have recently demonstrated the feasibility of nucleophilic aromatic substitutions on similar quinazoline substrates under simple acidic conditions. ${ }^{16-18}$

Accordingly, the dichloroquinazoline 1 was treated with 3-chloro-4-fluoroaniline in 20.4 equivalents of acetic acid at $55{ }^{\circ} \mathrm{C}$ for two hours to yield the coupling product 2 after extraction with EtOAc and filtration (Scheme 4). Under these conditions, we were able to isolate the desired 4-aminated product 2 exclusively in $65 \%$ yield on a multigram scale. Not unexpectedly, however, the ensuing selective demethylation of $\mathbf{2}$ proved challenging (Table 1 ). A variety of conditions were tested, including L-methionine in methanesulfonic acid (Table 1, entry 1). However, these conditions mainly afforded decomposition products at the high temperatures that proved necessary for significant conversion. Interestingly, $\mathrm{BBr}_{3}$ provided the bisdemethylated product exclusively (entry 2 ). When we experimented with
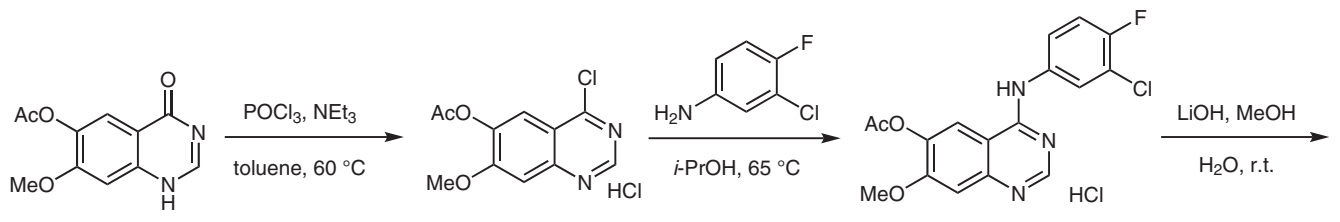<smiles>COc1cc2ncnc(Nc3ccc(F)c(Cl)c3)c2cc1O</smiles>

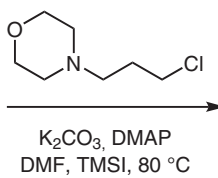<smiles>COc1cc2ncnc(Nc3ccc(F)c(Cl)c3)c2cc1OCCCN1CCOCC1</smiles>

Scheme 3 Suh and co-workers' synthesis of gefitinib ${ }^{13}$ 
<smiles>COc1cc2nc(Cl)nc(Cl)c2cc1OC</smiles><smiles>COc1cc2nc(Cl)nc(Nc3ccc(F)c(Cl)c3)c2cc1OC</smiles><smiles>COc1cc2nc(Cl)nc(Nc3ccc(F)c(Cl)c3)c2cc1O</smiles><smiles>COc1cc2nc(Cl)nc(Nc3ccc(F)c(Cl)c3)c2cc1OCCCN1CCOCC1</smiles>

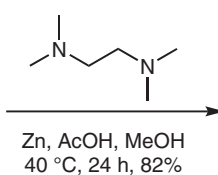

$40{ }^{\circ} \mathrm{C}, 24 \mathrm{~h}, 82 \%$<smiles>COc1cc2ncnc(Nc3ccc(F)c(Cl)c3)c2cc1OCCCN1CCOCC1</smiles>

5 (Gefitinib)

Scheme 4 Dichloroquinazoline as a new starting material for gefitinib preparation

various additives to $\mathrm{BBr}_{3}$ to control the rate of demethylation, we either observed no reaction (NR) or a complex mixture of products (entries 3 and 4). Another Lewis acid, aluminum iodide $\left(\mathrm{AlI}_{3}\right)$, also showed no reaction at low temperatures (entry 5). Aluminum chloride $\left(\mathrm{AlCl}_{3}\right)$ showed a robust rate of conversion but, even in the presence of sodium iodide ( $\mathrm{NaI}$ ), at best provided a 1:1 ratio of demethylated isomers that were difficult to separate (entries 6-7). With ethanethiol as an additive, a favorable 1:0.4 ratio was obtained, but in low yield (entry 8). Reaction times longer than two days were required for high conversions.
In an attempt to accelerate the reaction without recourse to excessive heating that could potentially lead to deamination byproducts and quinazoline ring opening, we explored the cleavage of methyl ethers through the use of ionic liquid (IL) reagents, including trimethylammonium heptachlorodialuminate $\left\{[\mathrm{TMAH}]\left[\mathrm{Al}_{2} \mathrm{Cl}_{7}\right]\right\} .{ }^{19}$ The IL demethylation mechanism is similar to that of $\mathrm{AlCl}_{3}$; however, the IL contains a higher concentration of chloride ions, the nucleophilicity of which is enhanced, resulting in shorter reaction times. Furthermore, improved demethylation selectivity has been reported for bicyclic ring systems. ${ }^{19}$ The IL was synthesized in situ from aluminum trichloride and trimethylammonium chloride in dichloromethane, and was direct-

Table 1 Screening of Reagents and Conditions for Demethylation at the 6-Position of Intermediate 2<smiles>COc1cc2nc(Cl)nc(Nc3ccc(F)c(Cl)c3)c2cc1O</smiles>

3<smiles>COc1cc2c(Nc3ccc(F)c(Cl)c3)nc(Cl)nc2cc1O</smiles>

6<smiles>Oc1cc2nc(Cl)nc(Nc3ccc(F)c(Cl)c3)c2cc1O</smiles>

\begin{tabular}{|c|c|c|c|c|}
\hline Entry & Reagent(s) (equiv) & $\operatorname{Temp}\left({ }^{\circ} \mathrm{C}\right)$ & Solvent & Product(s) ${ }^{\mathrm{a}}$ \\
\hline 1 & L-methionine (1.2) & 150 & $\mathrm{MsOH}$ & - (dec.) \\
\hline 2 & $\mathrm{BBr}_{3}(3.0)$ & r.t. & $\mathrm{CH}_{2} \mathrm{Cl}_{2}$ & $7^{b}$ \\
\hline 3 & $\mathrm{ZrCl}_{2}(2.0), \mathrm{BBr}_{3}(1.0)$ & 50 & $\mathrm{CH}_{2} \mathrm{Cl}_{2}$ & NR \\
\hline 4 & $\mathrm{TiCl}_{4}(2.0), \mathrm{BBr}_{3}(1.0)$ & 45 & $\mathrm{CH}_{2} \mathrm{Cl}_{2}$ & mixture \\
\hline 5 & $\mathrm{All}_{3}$ (1.5), PhSH (1.5) & 0 & $\mathrm{CH}_{2} \mathrm{Cl}_{2}$ & NR \\
\hline 6 & $\mathrm{AlCl}_{3}(3.0)$ & r.t. & $\mathrm{CH}_{2} \mathrm{Cl}_{2}$ & $3,6^{c}$ \\
\hline 7 & $\mathrm{AlCl}_{3}$ (3.0), Nal (3.0) & r.t. & $\mathrm{CH}_{2} \mathrm{Cl}_{2}$ & 3,6 \\
\hline 8 & $\mathrm{AlCl}_{3}$ (3.0), EtSH (2.0) & 40 & $\mathrm{CH}_{2} \mathrm{Cl}_{2}$ & $3,6^{d}$ \\
\hline 9 & {$[\mathrm{TMAH}]\left[\mathrm{Al}_{2} \mathrm{Cl}_{7}\right](3.0)$} & 50 & $\mathrm{CH}_{2} \mathrm{Cl}_{2}$ & $3,6^{\mathrm{e}}$ \\
\hline
\end{tabular}

${ }^{\text {a }}$ Products and product ratios were determined by LC/MS and ${ }^{19} \mathrm{~F}$ NMR analyses.

b The bisdemethylated product 7 was formed exclusively.

c $A$ 1:1 ratio of demethylated isomers and the starting material was detected that could not readily be enriched in the desired product through crystallization.

${ }^{d}$ A 1:0.4 ratio of phenols 3 and 6 was formed in low yield.

e A 1.3:1 ratio of phenols 3 and $\mathbf{6}$ was enriched to a 97:3 ratio in the first crystallization batch favoring the desired product $\mathbf{3}$. 
ly used for the demethylation step in a one-pot protocol. With intermediate $\mathbf{2}$, we found that treatment with [TMAH] $\left[\mathrm{Al}_{2} \mathrm{Cl}_{7}\right]$ at $50{ }^{\circ} \mathrm{C}$ for two hours gave a $1.1-1.3$ to 1 ratio of monodemethylated regioisomers; however, a favorable $>95: 5$ ratio of the desired product could readily be obtained in 30-35\% yield without chromatography by crystallization of the concentrated reaction mixture from hot methanol. Although not required for the next step, a second crystallization increased the regioisomeric purity to $>99 \%$.

The IL was freshly prepared before each use, and was not concentrated as suggested in the original publication, ${ }^{19}$ because we found that removal of the solvent generally resulted in a less active reagent. The one-pot protocol also simplified the experimental protocol. Significantly, the synthesis of [TMAH] $\left[\mathrm{Al}_{2} \mathrm{Cl}_{7}\right]$ IL is cost effective, and its feasibility for chemical-process applications has already been demonstrated on $7 \mathrm{~kg}$ scale. ${ }^{20}$

Previous syntheses mainly used DMF, sodium and potassium carbonates, and high temperatures for the O-alkylation step. We found that sodium and potassium carbonates were not effective at low temperatures in DMSO. In contrast, the reaction of $\mathbf{3}$ with 4-(3-chloropropyl)morpholine in the presence of cesium carbonate in DMSO at $40{ }^{\circ} \mathrm{C}$ for 2.5 hours provided ether 4 in $80 \%$ yield after filtration and crystallization from hot methanol. The FDA classifies DMF as a more-hazardous Class 2 solvent, whereas DMSO is a less-hazardous Class 3 solvent; therefore, these conditions were in agreement with our goal of minimizing the use of toxic or controlled reagents. ${ }^{21}$

The final dehalogenation step in the conversion of $\mathbf{4}$ to 5 required considerable optimization. Palladium(II) acetate in the presence of hydrogen gas provided no control of selectivity and resulted in complete dechlorination to $\mathbf{8}$ (Figure 1 ), as well as loss of aniline, among other side reactions. Similarly, hydrogenation with $10 \%$ Pd on carbon resulted in the loss of the quinazoline chlorine as well as the aniline chlorine atoms to give predominantly $\mathbf{8}$. Attempts at hydrogenation by using Lindlar's catalyst or Raney nickel both provided only trace conversions to the desired product $\mathbf{5}$, along with varying amounts of the bisdechlorinated derivative 8. Similarly unsatisfactory results were obtained by using a combination of $\mathrm{NaBH}_{4}$ and TMEDA under palladium catalysis. ${ }^{22}$ However, a chemoselective conversion was finally realized by using zinc and acetic acid in the presence of tetrabutylammonium bromide $\left(\mathrm{Bu}_{4} \mathrm{NBr}\right)$ as an additive, a reagent combination that had previously been shown to reduce a chloropyridine substrate selectively. ${ }^{23}$ In addition to the desired product $\mathbf{5}$, under these conditions we also observed that small amounts of 3-chloro-4-fluoroaniline were formed, which probably originated from an acid-mediated solvolysis of the quinazoline moiety. This side reaction could be suppressed through a modification employing zinc and $N, N, N^{\prime}, N^{\prime}$-tetramethylethylenediamine (TMEDA) in a mixture of $\mathrm{MeOH}$ and $\mathrm{AcOH}$ to achieve the desired dehalogenation of $\mathbf{4}$ exclusively. After stirring the reaction mixture at $40{ }^{\circ} \mathrm{C}$ for 24 hours, 2-mercaptonicotinic acid was added to assist in the removal of excess zinc and zinc salts. ${ }^{24}$ Finally, we were able to crystallize the product from hot $\mathrm{MeOH}$ to provide gefitinib (5) as colorless crystals in $82 \%$ yield with $>99 \%$ purity as determined by LC/MS analysis. ${ }^{25}$
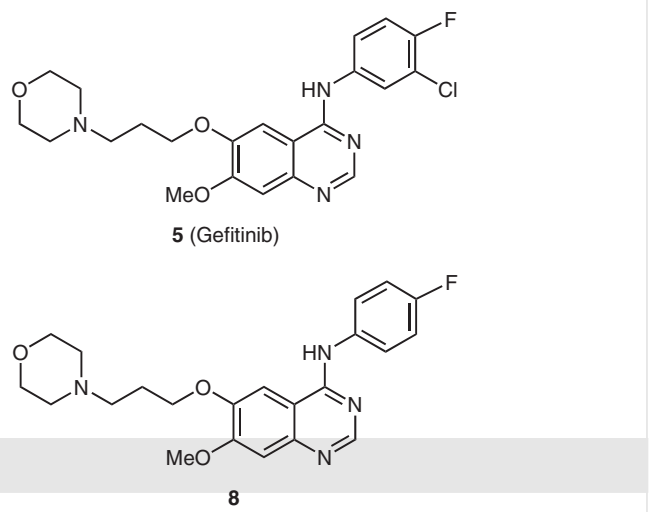

Figure 1 Products observed in the dechlorination of 4

In conclusion, a gram-scale synthesis of gefitinib was accomplished in four steps from commercially available 2,4-dichloro-6,7-dimethoxyquinazoline. Reaction temperatures did not exceed $55^{\circ} \mathrm{C}$, and workup procedures took advantage of the superior crystallization properties of the $\mathrm{C}(2)$-chlorinated quinazolines in methanol. Thus, all purifications were performed by filtrations or crystallizations. No protective groups were required, and reagents such as DMF, $\mathrm{SOCl}_{2}, \mathrm{POCl}_{3}$, and TMSI were avoided. A new application of an ionic liquid streamlined the demethylation step, and a selective dehalogenation by using zinc, acetic acid, and TMEDA proved successful.

\section{Funding Information}

This work was partially supported by Sterling, Perugia, Italy.

\section{Acknowledgement}

The authors are grateful to the staff and chemists at Sterling, Perugia, Italy, for partial financial support of this work, and for many stimulating questions.

\section{Supporting Information}

Supporting information for this article is available online at https://doi.org/10.1055/s-0037-1610375.

\section{References and Notes}

(1) Gridelli, C.; De Marinis, F.; Di Maio, M.; Cortinovis, D.; Cappuzzo, F.; Mok, T. Lung Cancer 2011, 72, 249.

(2) Siegel, R. L.; Miller, K. D.; Jemal, A. CA-Cancer J. Clin. 2007, 67, 7. 
(3) da Cunha Santos, G.; Shepherd, F. A.; Tsao, M. S. Annu. Rev. Pathol.: Mech. Dis. 2011, 6, 49.

(4) Bogdanowicz, B. S.; Hoch, M. A.; Hartranft, M. E. J. Oncol. Pharm. Pract. 2017, 23, 203.

(5) Knesl, P.; Röseling, D.; Jordis, U. Molecules 2006, 11, 286.

(6) Zheng, Y.; Li, M.; Zhang, S.; Ji, M. J. Chem. Res. 2009, 388.

(7) Chandregowda, V.; Rao, G. V.; Reddy, G. C. Synth. Commun. 2007, 37, 3409.

(8) Chandrasekhar, M.; Srinivasulu, D.; Seshaiah, K.; Kumar, N. Pharm. Chem. J. 2014, 48, 520.

(9) Li, F.; Feng, Y.; Meng, Q.; Li, W.; Li, Z.; Wang, Q.; Tao, F. ARKIVOC 2007, (i), 40.

(10) Gibson, K. H. US 5770599, 1998.

(11) Bretherick, L. 3rd ed. Hazards in the Chemical Laboratory; Royal Society of Chemistry: London, 1981, 503.

(12) Chandregowda, V.; Rao, G. V.; Reddy, G. C. Org. Process Res. Dev. 2007, 11, 813.

(13) Kang, S. K.; Lee, S. W.; Woo, D.; Sim, J.; Suh, Y.-G. Synth. Commun. 2017, 47, 1990.

(14) Anon, Dangerous Prop. Ind. Mater. Rep. 1995, 15, 354.

(15) Wipf, P.; George, K. M. Synlett 2010, 644.

(16) Hao, C.; Zhao, F.; Song, H.; Guo, J.; Li, X.; Jiang, X.; Huan, R.; Song, S.; Zhang, Q.; Wang, R.; Wang, K.; Pang, Y.; Liu, T.; Lu, T.; Huang, W.; Wang, J.; Lin, B.; He, Z.; Li, H.; Li, F.; Zhao, D.; Cheng, M. J. Med. Chem. 2018, 61, 265.

(17) Iwaki, T.; Nakamura, Y.; Tanaka, T.; Ogawa, Y.; Iwamoto, O.; Okamura, Y.; Kawase, Y.; Furuya, M.; Oyama, Y.; Nagayama, T. Bioorg. Med. Chem. Lett. 2017, 27, 4904.

(18) Park, H.; Jung, H.-Y.; Mah, S.; Hong, S. Angew. Chem. Int. Ed. 2017, 56, 7634.

(19) Kemperman, G. J.; Roeters, T. A.; Hilberink, P. W. Eur. J. Org. Chem. 2003, 1681.

(20) Kemperman, G. J.; Ter Horst, B.; Van de Goor, D.; Roeters, T.; Bergwerff, J.; Van der Eem, R.; Basten, J. Eur. J. Org. Chem. 2006, 3169.

(21) Anon; Q3C - Tables and List Guidance for Industry: Revision 4; U.S. Department of Health and Human Services Food and Drug Administration, Center for Drug Evaluation and Research (CDER), Center for Biologics Evaluation and Research (CBER): Silver Springs, 2018; https://www.fda.gov/downloads/ drugs/guidances/ucm073395.pdf

(22) Chelucci, G.; Figus, S. J. Mol. Catal. A: Chem. 2014, 393, 191.

(23) Röver, S.; Andjelkovic, M.; Bénardeau, A.; Chaput, E.; Guba, W.; Hebeisen, P.; Mohr, S.; Nettekoven, M.; Obst, U.; Richter, W. F.; Ullmer, C.; Waldmeier, P.; Wright, M. B. J. Med. Chem. 2013, 56, 9874.

(24) Yee, N. K.; Farina, V.; Houpis, I. N.; Haddad, N.; Frutos, R. P.; Gallou, F.; Wang, X.-J.; Wei, X.; Simpson, R. D.; Feng, X.; Fuchs, V.; Xu, Y.; Tan, J.; Zhang, L.; Xu, J.; Smith-Keenan, L. L.; Vitous, J.; Ridges, M. D.; Spinelli, E. M.; Johnson, M.; Donsbach, K.; Nicola, T.; Brenner, M.; Winter, E.; Kreye, P.; Samstag, W. J. Org. Chem. 2006, 71,7133 .

(25) 2-Chloro- $N$-(3-chloro-4-fluorophenyl)-6,7-dimethoxyquinazolin-4-amine (2)

A vigorously stirred, pale-pink, homogeneous solution of 3chloro-4-fluoroaniline $(3.37 \mathrm{~g}, 23.2 \mathrm{mmol})$ in $\mathrm{AcOH}(22.5 \mathrm{~mL}$, $394 \mathrm{mmol}$ ) was treated at $45{ }^{\circ} \mathrm{C}$ with neat 2,4-dichloro-6,7dimethoxyquinazoline $(\mathbf{1} ; 5.00 \mathrm{~g}, 19.3 \mathrm{mmol})$ in a single batch. The temperature was monitored with an internal thermometer. After the addition was complete $(1 \mathrm{~min})$, the resulting mixture was warmed to $55^{\circ} \mathrm{C}$ for a total of $2 \mathrm{~h}$. The pink solution turned viscous and then solidified after about $30 \mathrm{~min}$, after which the magnetic stirring was stopped. TLC analysis after $2 \mathrm{~h}$ showed that the aniline was consumed, some quinazoline starting material remained, and the product had formed [5\% $\mathrm{MeOH}-\mathrm{CH}_{2} \mathrm{Cl}_{2}$; quinazoline: $R_{f}=0.85$, aniline: $R_{f}=0.7$; product 2: $R_{f}=0.2$; byproduct $(<5 \%$; aniline dimer addition product): $R_{f}=0.1$. The solid pink mixture was cooled to $40{ }^{\circ} \mathrm{C}$ then dissolved in warm EtOAc $\left(0.50 \mathrm{~L}, 40^{\circ} \mathrm{C}\right)$ and $2 \mathrm{M}$ aq $\mathrm{NaOH}(275 \mathrm{~mL})$ with vigorous agitation. The solution was transferred to a separatory funnel and vigorously shaken. The layers were separated and the aqueous layer $(\sim \mathrm{pH} 10)$ was back-extracted with EtOAc $(2 \times 100 \mathrm{~mL})$. The combined organic layers were extracted with $0.5 \mathrm{M}$ aq $\mathrm{NaOH}(2 \times 100 \mathrm{~mL})$, dried $\left(\mathrm{Na}_{2} \mathrm{SO}_{4}, \sim 40 \mathrm{~g}\right)$, filtered, and concentrated $(75 \mathrm{~mL})$. The precipitate was collected by filtration and washed with EtOAc $(40 \mathrm{~mL})$ to yield a white powder that was dried in vacuo $\left(0.5 \mathrm{Torr}, 20^{\circ} \mathrm{C}\right)$ to yield a first batch of product (yield: $3.99 \mathrm{~g}$ ). The original organic filtrate was then further concentrated to $37.5 \mathrm{~mL}$, and the precipitate was collected by filtration and washed with additional EtOAc $(\sim 20 \mathrm{~mL})$ to afford a second batch of product $(0.60 \mathrm{~g})$. After ${ }^{1} \mathrm{H}$ and ${ }^{19} \mathrm{~F}$ NMR analysis, the two batches were combined to give a colorless solid; yield: $4.59 \mathrm{~g}(12.5 \mathrm{mmol}, 65 \%) ; \mathrm{mp} 273.0-275.8^{\circ} \mathrm{C}$; TLC: $R_{f}=0.2$ (5\% MeOH- $\mathrm{CH}_{2} \mathrm{Cl}_{2}$ ); IR (ATR, neat): 3387,2980 , 1980, 1623, 1573, 1500, 1457, 1342, 1217, 1147, 997, 963, 846, $795 \mathrm{~cm}^{-1} .{ }^{1} \mathrm{H}$ NMR $\left(400 \mathrm{MHz}\right.$, DMSO- $\left.d_{6}\right): \delta=9.92(\mathrm{~s}, 1 \mathrm{H}), 8.00$ (dd, $J=6.8,2.8 \mathrm{~Hz}, 1 \mathrm{H}), 7.84(\mathrm{~s}, 1 \mathrm{H}), 7.76-7.72(\mathrm{~m}, 1 \mathrm{H}), 7.50$ (app t, J=9.2 Hz, $1 \mathrm{H}), 7.20$ (s, $1 \mathrm{H}), 3.95(\mathrm{~s}, 3 \mathrm{H}), 3.93(\mathrm{~s}, 3 \mathrm{H}) .{ }^{13} \mathrm{C}$ NMR $\left(100 \mathrm{MHz}\right.$, DMSO- $\left.d_{6}\right): \delta=158.2,155.6,154.4,153.1,149.6$, 148.7, 136.3, 124.7, 123.5, 119.6, 117.4, 107.6, 107.2, 102.5, 56.8, 56.5. ${ }^{19} \mathrm{~F}$ NMR (376 MHz, DMSO- $d_{6}$ ): $\delta=-121.9$; HRMS (LC/MS, ESI+): $m / z[\mathrm{M}+\mathrm{H}]^{+}$calcd for $\mathrm{C}_{16} \mathrm{H}_{13} \mathrm{Cl}_{2} \mathrm{FN}_{3} \mathrm{O}_{2}: 368.0363$; found: 368.0361 .

[TMAH] $\left[\mathrm{Al}_{2} \mathrm{Cl}_{7}\right]$

A suspension of $\mathrm{AlCl}_{3}(9.00 \mathrm{~g}, 67.5 \mathrm{mmol})$ in $\mathrm{CH}_{2} \mathrm{Cl}_{2}(67.5 \mathrm{~mL})$ was cooled in an ice bath and treated by portionwise addition of $\mathrm{Me}_{3} \mathrm{NH}^{+} \mathrm{Cl}^{-}(3.23 \mathrm{~g}, 33.7 \mathrm{mmol})$. After addition was complete, the reaction mixture was warmed to r.t. and stirred for $2 \mathrm{~h}$. This mixture (12.2 $\mathrm{g}$ in $67.5 \mathrm{~mL} \mathrm{CH}_{2} \mathrm{Cl}_{2}$ ) was used in the subsequent reaction without further purification or concentration.

2-Chloro-4-[(3-chloro-4-fluorophenyl)amino]-7-methoxyquinazolin-6-ol (3)

A suspension of quinazolinamine $2(4.11 \mathrm{~g}, 11.2 \mathrm{mmol})$ in $\mathrm{CH}_{2} \mathrm{Cl}_{2}(11 \mathrm{~mL})$ was added in two portions to a freshly prepared solution of [TMAH] $\left[\mathrm{Al}_{2} \mathrm{Cl}_{7}\right](12.2 \mathrm{~g}, 33.5 \mathrm{mmol})$ in $\mathrm{CH}_{2} \mathrm{Cl}_{2}(67.5$ $\mathrm{mL})$. The first batch $(7.0 \mathrm{~mL})$ was added at a rate of $1 \mathrm{~mL} / \mathrm{min}$, and the second batch, along with a rinse of $\mathrm{CH}_{2} \mathrm{Cl}_{2}(4.0 \mathrm{~mL})$, was added at a rate of $2 \mathrm{~mL} / \mathrm{min}$. The reaction mixture was then magnetically stirred and heated for $2 \mathrm{~h}$ at reflux, while the external temperature was maintained at $\sim 50^{\circ} \mathrm{C}$. After $1 \mathrm{~h}$, a light-brown suspension formed. TLC analysis (5\% $\mathrm{MeOH}-$ $\mathrm{CH}_{2} \mathrm{Cl}_{2}$ ) after $2 \mathrm{~h}$ showed that the starting material had been consumed and a product spot corresponding to the mixture of phenol regioisomers had formed $\left(R_{f}=0.4\right)$. The suspension was cooled to $0{ }^{\circ} \mathrm{C}$, and $2 \mathrm{M}$ aq $\mathrm{HCl}(\sim 200 \mathrm{~mL})$ was added dropwise from an addition funnel at a rate of $4.0 \mathrm{~mL} / \mathrm{min}$ over $50 \mathrm{~min}$ while the rapidly forming suspension was stirred vigorously. The internal temperature of the solution was maintained below $20{ }^{\circ} \mathrm{C}$ to avoid solvent evaporation. After complete addition of the $2 \mathrm{M}$ aq $\mathrm{HCl}$, the resulting mixture $(\mathrm{pH}=0)$ was filtered through a fritted glass funnel $(\sim 200 \mathrm{~mL}$ of filtrate was collected). The collected filter cake was washed with $\mathrm{H}_{2} \mathrm{O}(2 \times 40 \mathrm{~mL})$ and briefly dried by vacuum filtration to give $\sim 50 \mathrm{~g}$ of a viscous residue that was transferred into a round-bottomed flask and concentrated by rotary evaporation under vacuum until a slurry (about 15-16 g) was obtained. This residue was suspended in 
hot $\mathrm{MeOH}(100 \mathrm{~mL})$, heated to reflux for $10 \mathrm{~min}$, and then allowed to cool and precipitate for $6 \mathrm{~h}$ while stirring was maintained. The solid was collected by filtration, washed with $\mathrm{MeOH}$ $(10 \mathrm{~mL})$ and dried in vacuo $\left(0.5 \mathrm{Torr}, 20^{\circ} \mathrm{C}\right)$ to give as a white solid consisting of a 97:3 mixture of regioisomers; yield: $1.26 \mathrm{~g}$ (3.56 mmol, 32\%)

\section{Major Regioisomer 3}

Mp 335.4-336. ${ }^{\circ} \mathrm{C}$; TLC: $R_{f}=0.4\left(5 \% \mathrm{MeOH}-\mathrm{CH}_{2} \mathrm{Cl}_{2}\right)$; IR (ATR, neat): $3392,2555,1620,1571,1517,1498,1421,1350,1283$, 1216, 1157, 1010, 973, 844, 802, $735 \mathrm{~cm}^{-1}$. ${ }^{1} \mathrm{H}$ NMR $(400 \mathrm{MHz}$, DMSO- $\left.d_{6}\right): \delta=9.86(\mathrm{~s}, 1 \mathrm{H}), 9.83(\mathrm{~s}, 1 \mathrm{H}), 8.09(\mathrm{dd}, J=6.8,2.8 \mathrm{~Hz}$, $1 \mathrm{H}$ ), 7.80-7.76 (m, $2 \mathrm{H}), 7.46$ (app t, $J=9.2 \mathrm{~Hz}, 1 \mathrm{H}), 7.20(\mathrm{~s}, 1$ H), 3.97 (s, $3 \mathrm{H}) .{ }^{13} \mathrm{C}$ NMR $\left(100 \mathrm{MHz}\right.$, DMSO- $\left.d_{6}\right): \delta=157.5,154.7$, 153.2, 152.3, 147.3, 147.0, 136.2, 123.6, 122.5, 118.8, 116.5, 107.9, 106.7, $105.7,56.1 .{ }^{19} \mathrm{~F}$ NMR (376 MHz, DMSO- $\left.d_{6}\right): \delta=$ -122.4; HRMS (LC/MS, ESI+): $m / z[\mathrm{M}+\mathrm{H}]^{+}$calcd for $\mathrm{C}_{15} \mathrm{H}_{11}{ }^{-}$ $\mathrm{Cl}_{2} \mathrm{FN}_{3} \mathrm{O}_{2}: 354.0207$; found: 354.0208 .

Characteristic Signals for Minor Regioisomer: 2-Chloro-4[(3-chloro-4-fluorophenyl)amino]-6-methoxyquinazolin-7ol (6)

${ }^{1} \mathrm{H}$ NMR $\left(400 \mathrm{MHz}\right.$, DMSO- $\left.d_{6}\right): \delta=10.67(\mathrm{~s}, 1 \mathrm{H}) .{ }^{19} \mathrm{~F}$ NMR (376 MHz, DMSO- $\left.d_{6}\right): \delta=-122.0$.

2-Chloro- $N$-(3-chloro-4-fluorophenyl)-7-methoxy-6-(3morpholin-4-ylpropoxy)quinazolin-4-amine (4)

A solution of quinazolinol 3 (1.25 g, $3.53 \mathrm{mmol}$ ), 4-(3-chloropropyl)morpholine $(0.59 \mathrm{~mL}, 3.9 \mathrm{mmol})$, and $\mathrm{Cs}_{2} \mathrm{CO}_{3}(2.30 \mathrm{~g}$, $7.06 \mathrm{mmol})$ in degassed DMSO $(10.0 \mathrm{~mL})$ was stirred at $40{ }^{\circ} \mathrm{C}$ under $\mathrm{N}_{2}$, while the reaction was monitored by TLC $(5 \%$ $\mathrm{MeOH}-\mathrm{CH}_{2} \mathrm{Cl}_{2}$; starting material: $R_{f}=0.4$; product 3: $R_{f}=0.3$ ). After $2.5 \mathrm{~h}$, the mixture was cooled to r.t., diluted with EtOAc $(100 \mathrm{~mL})$, and extracted. The organic layer was washed sequentially with sat. aq $\mathrm{NaHCO}_{3}(2 \times 25 \mathrm{~mL}), 1 \mathrm{M}$ aq $\mathrm{LiCl}(7.5 \mathrm{~mL})$, and $2 \mathrm{M}$ aq $\mathrm{NaOH}(7.5 \mathrm{~mL})$. The aqueous layer $(\mathrm{pH}>12)$ was then back-extracted with EtOAc $(2 \times 50 \mathrm{~mL})$, and the combined organic layers were dried $\left(\mathrm{Na}_{2} \mathrm{SO}_{4}, 12 \mathrm{~g}\right)$, filtered, rinsed with EtOAc ( $15 \mathrm{~mL})$, and concentrated. The crude residue $(2.02 \mathrm{~g})$ was heated at reflux in $\mathrm{MeOH}(20 \mathrm{~mL})$ for $10 \mathrm{~min}$, and then allowed to precipitate overnight at r.t. The solids were collected by filtration, washed with $\mathrm{MeOH}(10 \mathrm{~mL})$, and dried in vacuo $(0.5$ Torr, $20^{\circ} \mathrm{C}$ ) to afford a colorless solid; yield: $1.36 \mathrm{~g}, 2.82 \mathrm{mmol}$ (80\%); mp 213.7-217.3 ${ }^{\circ} \mathrm{C}$; TLC: $R_{f}=0.3\left(5 \% \mathrm{MeOH}-\mathrm{CH}_{2} \mathrm{Cl}_{2}\right.$ ); IR (ATR, neat): 3329, 2813, 1945, 1623, 1578, 1499, 1430, 1290, 1221, 1149, 1110, 1013, 960, 852, $735 \mathrm{~cm}^{-1} .{ }^{1} \mathrm{H}$ NMR (400 MHz, DMSO- $\left.d_{6}\right): \delta=9.92(\mathrm{~s}, 1 \mathrm{H}), 8.00(\mathrm{dd}, J=6.8,2.8 \mathrm{~Hz}, 1 \mathrm{H}), 7.83(\mathrm{~s}$, $1 \mathrm{H}), 7.76-7.73(\mathrm{~m}, 1 \mathrm{H}), 7.50$ (app t, $J=9.2 \mathrm{~Hz}, 1 \mathrm{H}), 7.19(\mathrm{~s}, 1$ $\mathrm{H}), 4.17(\mathrm{t}, J=6.4 \mathrm{~Hz}, 2 \mathrm{H}), 3.93(\mathrm{~s}, 3 \mathrm{H}), 3.58(\mathrm{app} \mathrm{t}, J=4.4 \mathrm{~Hz}, 4$
H), 2.49-2.45 (m, $2 \mathrm{H}$ ), 2.38 (br s, $4 \mathrm{H}), 2.01-1.98$ (m, $2 \mathrm{H}) .{ }^{13} \mathrm{C}$ NMR $\left(100 \mathrm{MHz}\right.$, DMSO- $\left.d_{6}\right): \delta=158.2,155.7,154.4,153.0,149.0$, 148.6, 136.3, 124.8, 123.6, 119.5, 119.4, 117.3, 117.1, 107.6, 107.2, 103.3, 67.7, 66.6, 56.6, 55.4, 53.9, 26.3. ${ }^{19} \mathrm{~F}$ NMR (376 MHz, DMSO- $d_{6}$ ): $\delta=-121.8$; HRMS (LC/MS, ESI + ): $m / z[\mathrm{M}+\mathrm{H}]^{+}$ calcd for $\mathrm{C}_{22} \mathrm{H}_{24} \mathrm{Cl}_{2} \mathrm{FN}_{4} \mathrm{O}_{3}$ : 481.1204; found: 481.1203.

$\mathbf{N}$-(3-Chloro-4-fluorophenyl)-7-methoxy-6-(3-morpholinopropoxy)quinazolin-4-amine (5; Gefitinib, Iressa)

AcOH (2.68 mL, $48.2 \mathrm{mmol}$ ) and quinazolinamine 4 (1.16 g, 2.41 $\mathrm{mmol}$ ) were added sequentially in dropwise manner to a suspension of $\mathrm{Zn}$ dust $(0.236 \mathrm{~g}, 36.1 \mathrm{mmol})$ and TMEDA (3.61 mL, $24.1 \mathrm{mmol})$ in $\mathrm{MeOH}(58.0 \mathrm{~mL})$ at $0{ }^{\circ} \mathrm{C}$. The mixture was then heated to $40-45^{\circ} \mathrm{C}$ for $24 \mathrm{~h}$, cooled to r.t., and diluted with

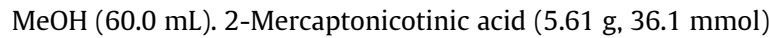
was added, and the suspension was vigorously stirred at r.t. for $30 \mathrm{~min}$, diluted with MTBE $(100 \mathrm{~mL})$, and washed with $2 \mathrm{M}$ aq $\mathrm{NaOH}(2 \times 100 \mathrm{~mL})$. The combined aqueous layers were backextracted with MTBE $(100 \mathrm{~mL})$, and the combined organic layers were washed with sat. aq $\mathrm{NaHCO}_{3}(100 \mathrm{~mL})$ then dried $\left(\mathrm{Na}_{2} \mathrm{SO}_{4}\right)$, filtered, and concentrated to give a yellow solid residue $(0.97 \mathrm{~g})$. This solid was dissolved in hot $\mathrm{MeOH}(30 \mathrm{~mL})$ and allowed to crystallize for $3 \mathrm{~h}$ at r.t. The colorless needles were collected by filtration, washed with MTBE $(10 \mathrm{~mL})$, and dried in vacuo $\left(0.5 \mathrm{Torr}, 20^{\circ} \mathrm{C}\right)$ to provide a first batch of the crystalline product $(0.84 \mathrm{~g})$. The mother liquor was then concentrated $(\sim 15 \mathrm{~mL})$ and allowed to crystallize overnight at r.t. The resulting crystals were collected by filtration and dried in vacuo $\left(0.5\right.$ Torr, $\left.20^{\circ} \mathrm{C}\right)$ to provide a second batch of product (0.090 g; mp $\left.188.5-190.6{ }^{\circ} \mathrm{C}\right)$, containing residual $\mathrm{MeOH}(\sim 4 \%$ by ${ }^{1} \mathrm{H}$ NMR), which was combined with the first batch. The product was further dried in vacuo $\left(0.5 \mathrm{Torr}, 80^{\circ} \mathrm{C}\right)$ for $24 \mathrm{~h}$ to provide a colorless solid; yield: $0.930 \mathrm{~g}(2.08 \mathrm{mmol}, 82 \%) ; \mathrm{mp}$ 195.7-197. ${ }^{\circ} \mathrm{C}$; TLC: $R_{f}=0.2$ (EtOH-EtOAc-hexanes); IR (ATR, neat): $3365,3160,1873,2816,1622,1578,1530,1497,1472$, 1426, 1393, 1353, 1280, 1217, 1112, 1044, 993, 957, 850, 772 $\mathrm{cm}^{-1} .{ }^{1} \mathrm{H}$ NMR $\left(400 \mathrm{MHz}, \mathrm{DMSO}-d_{6}\right): \delta=9.57(\mathrm{~s}, 1 \mathrm{H}), 8.50(\mathrm{~s}, 1$ $\mathrm{H}), 8.11(\mathrm{dd}, J=6.8,2.8 \mathrm{~Hz}, 1 \mathrm{H}), 7.81(\mathrm{~s}, 1 \mathrm{H}), 7.80-7.77(\mathrm{~m}, 1$ H), 7.45 (app t, $J=9.2 \mathrm{~Hz}, 1 \mathrm{H}), 7.21(\mathrm{~s}, 1 \mathrm{H}), 4.18(\mathrm{t}, J=6.0 \mathrm{~Hz}, 2$ H), $3.94(\mathrm{~s}, 3 \mathrm{H}), 3.58$ (app t, $J=4.4 \mathrm{~Hz}, 4 \mathrm{H}), 2.48-2.46(\mathrm{~m}, 2 \mathrm{H})$, 2.39 (br s, 4 H), 2.03-1.96 (m, 2 H). ${ }^{13} \mathrm{C}$ NMR (100 MHz, DMSO$\left.d_{6}\right): \delta=156.0,154.5,152.6,151.9,148.3,147.0,136.8,123.5$, 122.4, 118.8, 118.7, 116.6, 116.4, 108.8, 107.3, 102.5, 67.1, 66.2, 55.9, 55.0, 53.4, 25.9. ${ }^{19} \mathrm{~F}$ NMR (376 MHz, DMSO- $\left.d_{6}\right): \delta=-123.3$; HRMS (LC/MS, ESI+): $m / z[\mathrm{M}+\mathrm{H}]^{+}$calcd for $\mathrm{C}_{22} \mathrm{H}_{25} \mathrm{ClFN}_{4} \mathrm{O}_{3}$ : 447.1594; found: 447.1593 . 